\title{
Kaolin foliar spray improves olive tree performance and yield under sustained deficit irrigation
}

\author{
Cátia Brito $^{\mathrm{a}}$, Alexandre Gonçalves ${ }^{\mathrm{a}, \mathrm{b}, \mathrm{c}}$, Ermelinda Silva ${ }^{\mathrm{a}}$, Sandra Martins ${ }^{\mathrm{a}}$, Luís Pinto ${ }^{\mathrm{b}}$, \\ Luís Rocha $^{\mathrm{a}}$, Margarida Arrobas ${ }^{\mathrm{b}}$, Manuel Ângelo Rodrigues ${ }^{\mathrm{b}}$, José Moutinho-Pereira ${ }^{\mathrm{a}}$, Carlos \\ M. Correia ${ }^{\mathrm{a}, *}$ \\ ${ }^{\text {a } C I T A B}$ - Centre for the Research and Technology of Agro-Environmental and Biological Sciences, Universidade de Trás-os-Montes e Alto Douro, 5000-801 Vila Real, \\ Portugal \\ ${ }^{\mathrm{b}}$ MORE - Collaborative Laboratory Mountains of Research, Brigantia Ecopark, Bragança, Portugal



\section{A R T I C L E I N F O}

\section{Keywords:}

Climate change adaptation strategies

Crop yield

Olea europaea

Olive oil

Particle film

Photosynthesis

\begin{abstract}
A B S T R A C T
Regarding the foreseeing climate change is reasonable to expect harmful consequences to olive tree (Olea europaea L.), an iconic species of Mediterranean basin. In large areas of the Region, the sustained deficit irrigation (SDI) accounts with a reduced amount of water that might not be enough to keep the plant functioning at desirable levels. In this study the use of a reflective clay, kaolin, was evaluated in order to alleviate the negative summer stress effects on olive trees (cv. Cobrançosa) under an SDI system. Kaolin reduced the stomatal and the non-stomatal limitations to photosynthesis at high light intensity, improved plant water status, and decreased the oxidative damages. The amelioration of physiological and metabolic functions and the lower allocation of resources to summer stress tolerance mechanisms, allowed the KL-sprayed trees to increase crop yield, the oil yield and its oxidative stability, with the reduction of peroxide index and $\mathrm{K}_{232}$. Thus, the application of kaolin had a positive synergistic effect with SDI, especially important for semi-arid areas where water available for irrigation do not cover all the necessities.
\end{abstract}

\section{Introduction}

In the current settings, olive tree growing under the typical Mediterranean semi-arid environments are already affected by severe summer conditions, including low rainfall, excessive heat load and high daily irradiance (Brito et al., 2019a). Moreover, severe summer conditions and extreme climatic events are predicted to increase in frequency in most future climate scenarios, being Mediterranean region particularly susceptibel to climate change (IPCC, 2013). Although olive is a crop well-adapted to harsh conditions, summer related stresses have negative repercussions on water relations, carbon assimilation, oxidative pathways, growth, productivity and harvests quality (Greven et al., 2009; Servili et al., 2009; Cansev, 2012; Koubouris et al., 2015; Brito et al., 2018a, b, 2019a). In this sense, is reasonable to expect harmful consequences to plant growth and yield, which may jeopardize the economic viability of the sector. Among the constituents of summer stress, drought is usually the most critical, although it is highly exacerbated by the others (Brito et al., 2019a). Thus, when it is possible, irrigation is used to maintain olives performance and productivity. In fact, it has been demonstrated that improved plant physiological responses and high crop yields can be achieved with sustained deficit irrigation (SDI) strategies (Bacelar et al., 2007; Fernandes-Silva et al., 2010; Masmoudi et al., 2010). Nevertheless, due to the high severity of stress in some regions of the Mediterranean area during the summer season, the amount of available water to irrigate might not be enough to keep the plant performance at desirable levels. Kaolin, once sprayed as a suspension on leaf surface leaves a protective particle film as water evaporates, having been proven to be efficient in summer stress alleviation under moderate stressful conditions, with positive effects in plant water status, photosynthetic responses, yield and oil quality (Roussos et al., 2010; Denaxa et al., 2012; Nanos, 2015; Brito et al., 2018c, d, 2019b,2019c), but eventually losing its effectiveness with the increase in stress prevalence and/or intensity (Shellie and Glenn, 2008; Nanos, 2015; Brito et al., 2018c, 2019b,2019c). On the other hand, some studies

\footnotetext{
* Corresponding author.

E-mail address: ccorreia@utad.pt (C.M. Correia).
} 
argued that kaolin inhibits the maximum plant performance under optimum water status conditions (Denaxa et al., 2012; Boari et al., 2015; Brito et al., 2018c) and under low light conditions, as in cloudy days (Brito et al., 2018c). By other side, it was demonstrated that kaolin may have the potential to reduce yield loss of tomato plants under moderate water deficit (SDI with $60 \%$ depletion of total available water), but not under severe stress (SDI with $80 \%$ depletion of total available water) (AbdAllah, 2019), while in vine (Vitis vinifera) a lack of response with kaolin was recorded under SDI (Shellie and Glenn, 2008). In addition to the variability of information on kaolin use under SDI, no available information on olive tree orchards can be found on this regard.

Hence, with this study we aim to evaluate if kaolin application improves olive groves performance and yield and if influences harvests quality under a SDI system. For this propose, we studied the effects of kaolin application on (i) leaf physiological and biochemical variables, (ii) fruits physical characteristics, (iii) crop and oil yield, and (iv) olive oil quality.

\section{Materials and methods}

\subsection{Plant material and experimental set-up}

The experimental trial took place near Vila Flor, Northeast Portugal, at Quinta do Prado farm $\left(41^{\circ} 20^{\prime} 13.3^{\prime \prime} \mathrm{N}, 7^{\circ} 05^{\prime} 54.2^{\prime \prime} \mathrm{W}\right)$, during two consecutive growing seasons (2016 and 2017), on an organic 8-years-old olive orchard (Olea europaea L. cv. "Cobrançosa") planted at $7 \times 3.80 \mathrm{~m}$, with a density of 376 plants per hectare. The climate is typically Mediterranean, with some Atlantic influence. Under the Koppen-Geiger climate classification, Vila Flor is classified as Csb, a temperate climate with hot and dry summers and rainy winters (IPMA, 2019). The minimum and maximum air temperature and monthly precipitation recorded during the experimental period are shown in Table 1.

The field trials were carried out in a eutric Cambisol (WRB, 2014). The soil is loamy textured ( $61.7 \%$ sand, $18.3 \%$ silt, and $20.0 \%$ clay), alkaline ( $\mathrm{pH}$ 8.0) and showed mean levels of organic carbon (24.8 $\mathrm{g} \mathrm{kg}^{-1}$, Walkley-Black). Phosphorus and potassium levels were very high (respectively 226.5 and $230.0 \mathrm{mg} \mathrm{kg}^{-1}$, as determined by

Table 1

Mean values of medium (Tmed), minimum (Tmin) and maximum (Tmax) air temperature $\left({ }^{\circ} \mathrm{C}\right)$, medium (Hmed), minimum (Hmin) and maximum (Hmax) air humidity (\%) and total rainfall (mm) from June to October of 2016 and 2017 and at the measurement's days.

\begin{tabular}{|c|c|c|c|c|c|c|c|}
\hline Date & Tmed & Tmin & Tmax & Hmed & Hmin & Hmax & Rainfal \\
\hline \multicolumn{8}{|l|}{2016} \\
\hline Jun & 20.9 & 14.3 & 27.8 & 59.5 & 35.9 & 81.8 & 29.4 \\
\hline Jul & 25.8 & 18.2 & 33.5 & 45.9 & 26.4 & 67.5 & $10.2^{1}$ \\
\hline Jul 20th & 26.3 & 18.4 & 33.5 & 42.6 & 20.8 & 59.3 & 0 \\
\hline Aug & 25.5 & 18.1 & 33.5 & 43.5 & 24.4 & 64.1 & $20.2^{2}$ \\
\hline Aug 3rd & 27.6 & 20.3 & 35.5 & 38.8 & 20.0 & 60.2 & 0 \\
\hline Aug 17th & 21.6 & 16.0 & 28.9 & 57.9 & 37.1 & 71.1 & 0 \\
\hline Aug 31st & 25.5 & 18.2 & 32.9 & 47.2 & 26.7 & 69.0 & 0 \\
\hline Sep & 21.9 & 15.4 & 29.0 & 53.6 & 30.8 & 74.5 & $45.4^{3}$ \\
\hline Sep 19th & 19.7 & 12.4 & 26.7 & 49.6 & 31.7 & 74.0 & 0 \\
\hline Oct & 16.2 & 11.9 & 21.5 & 70.0 & 52.5 & 84.5 & $140.0^{4}$ \\
\hline Oct 11th & 14.9 & 9.8 & 21.0 & 66.1 & 45.7 & 87.8 & 0 \\
\hline Oct 25th & 15.1 & 12.0 & 19.5 & 82.9 & 72.3 & 88.5 & 14.4 \\
\hline \multicolumn{8}{|l|}{2017} \\
\hline Jun & 23.9 & 17.5 & 31.0 & 50.7 & 28.6 & 72.3 & $47.0^{5}$ \\
\hline Jul & 24.5 & 17.1 & 32.4 & 48.5 & 24.9 & 72.2 & 0.6 \\
\hline Jul 21st & 20.1 & 12.3 & 28.2 & 52.6 & 30.5 & 74.2 & 0 \\
\hline Aug & 24.0 & 17.0 & 31.6 & 45.8 & 24.0 & 67.5 & 0 \\
\hline Aug 10th & 20.5 & 12.4 & 27.7 & 37.4 & 21.4 & 60.8 & 0 \\
\hline Sep & 19.8 & 13.5 & 27.0 & 52.8 & 26.9 & 74.9 & $2.2^{6}$ \\
\hline Sep 6th & 27.0 & 22.5 & 31.0 & 25.1 & 14.5 & 38.5 & 0 \\
\hline Oct & 19.4 & 12.9 & 26.1 & 46.7 & 30.4 & 64.9 & $33.2^{7}$ \\
\hline Oct 12th & 21.3 & 12.6 & 30.8 & 25.1 & 16.5 & 38.8 & 0 \\
\hline
\end{tabular}

${ }^{1}$ days 5 th and 6 th; ${ }^{2}$ between 24 th and $26 \mathrm{th} ;{ }^{3} 43.2 \mathrm{~mm}$ on 13 th and 14 th; ${ }^{4}$ between 12 th and 25 th; ${ }^{5}$ day 6 th; ${ }^{6}$ day 18 th; ${ }^{7}$ days 17 th and 18 th.
Egnér-Riehm method), as well as exchangeable calcium and magnesium ( 25.0 and $6.2 \mathrm{cmol}_{\mathrm{c}} \mathrm{kg}^{-1}$, respectively, as determined by the ammonium acetate method). Leaf analysis revealed an orchard in good nutritional status, with all the essential elements falling within the sufficiency ranges established for the species (Bryson, 2014). A moderate formation pruning was made in February. No soil mineral fertilization was applied. The soil was managed by mowing the natural vegetation with a rotary brush cutter once a year by May. Trees were subjected to sustained deficit irrigation, which corresponded to a seasonal water amount equivalent to $27.5 \%$ of etc. A more detailed information about the irrigation can be found in Gonçalves et al. (2020). The trees were drip-irrigated by three drippers per tree (two at $1.5 \mathrm{~m}$ from the trunk and one near the trunk), each with a flow rate of $1.8 \mathrm{~L} / \mathrm{h}$, connected to a single drip line.

\subsection{Treatments applied and monitoring}

The experiment comprises two treatments: control (C) trees, sprayed with distilled water, and kaolin (KL), sprayed with an aqueous solution of KL (Surround ${ }^{\circledR}$ WP, Engelhard Corporation, Iselin, NJ), at the manufacturer recommended dosage of $5 \%(w / v)$. Each plant was treated with a mean volume of $750 \mathrm{~mL}$ of spraying solution. A second application in the same day was done to ensure the adhesion uniformity of kaolin clay particles. All spray applications were supplemented with $0.1 \%(\mathrm{v} / \mathrm{v})$ Tween 20 and conducted according to good efficacy practice standard operating procedures adjusted for agricultural experiments. The treatments were applied in the absence of wind on the mornings of July 8th, 2016 and June 6th, 2017.

The experimental trial included two adjacent plots, one per treatment, each with three rows, with sixteen olive trees per row, where only the central line was used for analysis, while the other two outer rows were considered buffer zones and excluded in sampling to avoid edge effects. Twelve trees of similar canopy size were selected from the central line of each treatment for analysis $(n=12)$. All the physiological and biochemical measurements done at leaf level were taken in healthy, full expanded and mature leaves. The leaf gas exchange, chlorophyll $a$ fluorescence, leaf relative water content and leaf density measurements were taken periodically during the two years of the study $(n=12)$. Photosynthetic light response curves were performed on July 20th 2016 $(n=3)$. Leaf biochemical analyses $(n=12)$ were done on samples collected once a year, on August 17th 2016 and on August 10th 2017. Crop yield $(n=12)$, fruit maturation index and fruit physical characteristics ( 3 samples of 200 fruits each) were accessed on October 25th, 2016 and on October 12th 2017. Oil extraction to determine oil yield and quality parameters $(n=3$, where each replicate was obtained from the fruits of 4 trees) was acquired from the harvest of October 2017. A schematic representation of the experiment procedure and the monitoring dates is presented in Fig. 1.

\subsection{Leaf gas exchange and chlorophyll a fluorescence}

Leaf gas exchange measurements were performed using a portable IRGA (LCpro+, ADC, Hoddesdon, UK), operating in the open mode, during the morning $(9: 00-10: 00 \mathrm{H})$ and midday (13:30-14:30) periods of summer cloudless days under natural irradiance. Net photosynthetic rate $\left(\mathrm{A}_{\mathrm{n}}, \mu \mathrm{mol} \mathrm{CO} \mathrm{CO}_{2} \mathrm{~m}^{-2} \mathrm{~s}^{-1}\right)$, stomatal conductance $\left(\mathrm{g}_{\mathrm{s}}, \mathrm{mmol} \mathrm{H}_{2} \mathrm{O} \mathrm{m} \mathrm{m}^{-2}\right.$ $\mathrm{s}^{-1}$ ), transpiration rate $\left(\mathrm{E}, \mathrm{mmol} \mathrm{H}_{2} \mathrm{O} \mathrm{m} \mathrm{m}^{-2} \mathrm{~h}^{-1}\right.$ ), and intercellular to atmospheric $\mathrm{CO}_{2}$ concentration $\left(\mathrm{C}_{\mathrm{i}} / \mathrm{C}_{\mathrm{a}}\right)$ ratio, were estimated using the equations developed by von Caemmerer and Farquhar (1981). Intrinsic water use efficiency was calculated as the ratio of $A_{n} / g_{s}\left(\mu \mathrm{mol} \mathrm{mol}^{-1}\right)$. After the midday measurements, photosynthetic light response curves were performed on some of the leaves used for gas exchange. The light response curves were produced by holding $\mathrm{CO}_{2}$ concentrations in the leaf chamber constant at $400 \mathrm{ppm}$ and varying light levels from 2000 to $0 \mu \mathrm{mol}$ photons $\mathrm{m}^{-2} \mathrm{~s}^{-1}$ using the light source provided with the equipment, which enabled automatic changes of photosynthetic photon 


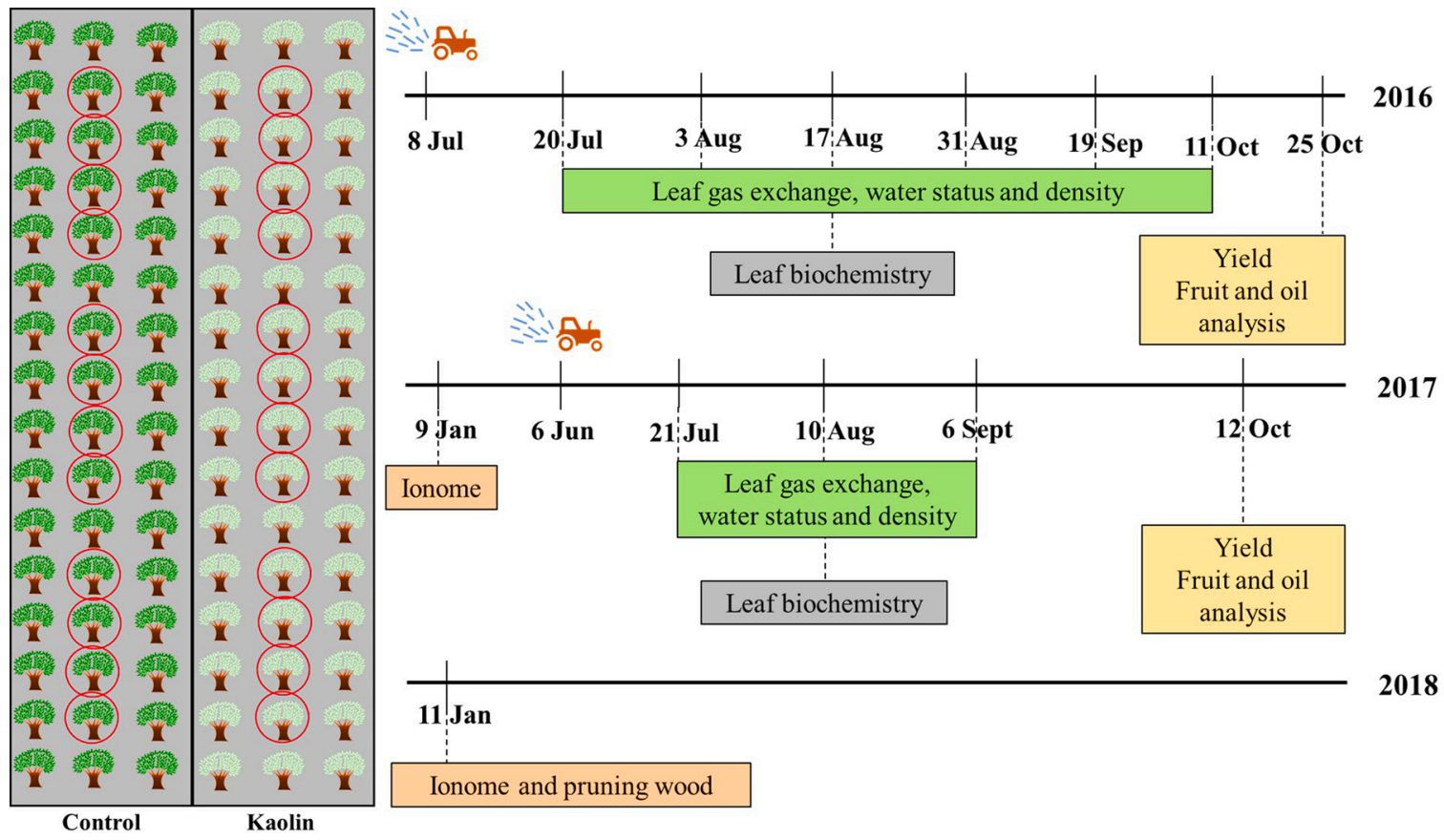

Fig. 1. Schematization of field trial and monitoring analysis performed during the experiment.

flux density $(2,000,1,500,1,000,800,500,300,200,100,50$ and $0 \mu \mathrm{mol}$ photons $\mathrm{m}^{-2} \mathrm{~s}^{-1}$ ), with $3-5$ min intervals. Data were then fitted with the non-rectangular hyperbola (Prioul and Chartier, 1977) and with the modified rectangular hyperbola (Ye, 2007) models. From the fitted equations, variables describing the light response curves were derived, including maximum photosynthetic assimilation rate (Amax), light compensation point (LCP, the light required for photosynthetic assimilation to balance respiration), light saturation point (LSP, light intensity beyond which there is no significant change in net photosynthesis), apparent quantum yield ( $\Phi$, the initial linear increase in photosynthetic assimilation within increasing light from LCP to $200 \mu \mathrm{mol} \mathrm{m}^{-2} \mathrm{~s}^{-1}$ ) and dark respiration rate $\left(\mathrm{Rd}\right.$, rate of $\mathrm{CO}_{2}$ production in darkness).

Chlorophyll $a$ fluorescence variables were measured in the same leaves and environmental conditions used for gas exchange measurements, with a pulse-amplitude-modulated fluorometer (FMS 2, Hansatech Instruments, Norfolk, England). Prior to the measurements, a small part of the leaves was dark-adapted for 30 min using dark-adapting leafclips. After this period, the minimal fluorescence $\left(\mathrm{F}_{0}\right)$ was measured when all photosystem II (PSII) reaction centers are open using a low intensity pulsed measuring light source. The maximal fluorescence $\left(\mathrm{F}_{\mathrm{m}}\right)$ was measured when all PSII reactions centers are closed during a pulse saturating light $\left(0.7 \mathrm{~s}\right.$ pulse of $15,000 \mu \mathrm{mol}$ photons $\mathrm{m}^{-2} \mathrm{~s}^{-1}$ of white light). The difference between these two levels $\left(F_{m}-F_{0}\right)$ is called variable fluorescence $\left(\mathrm{F}_{\mathrm{v}}\right)$. Maximum quantum efficiency of PSII was calculated as $F_{\mathrm{v}} / \mathrm{F}_{\mathrm{m}}=\left(\mathrm{F}_{\mathrm{m}}-\mathrm{F}_{0}\right) / \mathrm{F}_{\mathrm{m}}$ (Krause and Weis, 1991). On the other hand, on light-adapted leaves, after a $20 \mathrm{~s}$ exposure to actinic light $\left(1500 \mu \mathrm{mol} \mathrm{m}^{-2} \mathrm{~s}^{-1}\right)$, light-adapted steady-state fluorescence yield $\left(\mathrm{F}_{\mathrm{s}}\right)$ was averaged over $2.5 \mathrm{~s}$, followed by exposure to saturating light (15, $000 \mu \mathrm{mol} \mathrm{m}^{-2} \mathrm{~s}^{-1}$ ) for $0.7 \mathrm{~s}$ to establish F'm. The sample was then shaded for $5 \mathrm{~s}$ with a far-red light source to determine $\mathrm{F}^{\prime} 0$. From these measurements, several fluorescence attributes were calculated according to Bilger and Schreiber (1986) and Genty et al. (1989): photochemical quenching $\left(\mathrm{qP}=\left(\mathrm{F}_{\mathrm{m}}{ }^{\prime}-\mathrm{F}_{\mathrm{s}}\right) /\left(\mathrm{F}_{\mathrm{m}}{ }^{\prime}-\mathrm{F}_{0}{ }^{\prime}\right)\right)$, capture efficiency of excitation energy by open PSII reaction centers $\left(\mathrm{F}_{\mathrm{v}}{ }^{\prime} / \mathrm{F}_{\mathrm{m}}{ }^{\prime}=\left(\mathrm{F}_{\mathrm{m}}{ }^{\prime}-\mathrm{F}_{0}{ }^{\prime}\right) / \mathrm{F}_{\mathrm{m}}{ }^{\prime}\right)$ and effective quantum efficiency of PSII ( $\left(\right.$ PSII $\left.=\Delta \mathrm{F} / \mathrm{F}_{\mathrm{m}}{ }^{\prime}=\left(\mathrm{F}_{\mathrm{m}}{ }^{\prime}-\mathrm{F}_{\mathrm{s}}\right) / \mathrm{F}_{\mathrm{m}}{ }^{\prime}\right)$.

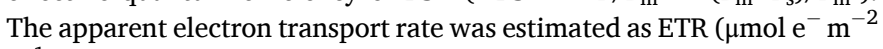
$\left.\mathrm{s}^{-1}\right)=\left(\Delta \mathrm{F} / \mathrm{F}_{\mathrm{m}}{ }^{\prime}\right) \mathrm{x}$ PPFD $\times 0.5 \times 0.84$, where PPFD is the photosynthetic photon flux density incident on the leaf, 0.5 is the factor that assumes equal distribution of energy between the two photosystems, and the leaf absorbance used was 0.84 , the most common value for C3 plants (Bilger and Schreiber, 1986).

\subsection{Leaf water status and density}

Leaves detached were immediately placed into air-tight containers and then the following parameters were examined: fresh weight (FW, g); weight at full turgor (TW, $g$ ), measured after immersion of leaf petioles in demineralized water for $48 \mathrm{~h}$ in the dark at $4{ }^{\circ} \mathrm{C}$; and dry weight (DW, g), measured after drying at $70^{\circ} \mathrm{C}$ to a constant weight. Further, was calculated the relative water content, RWC $(\%)=(\mathrm{FW}-\mathrm{DW}) /(\mathrm{TW}-$ DW) and the density of foliar tissue $\left(\mathrm{g} \mathrm{kg}^{-1}\right)=$ DW/FW.

\subsection{Foliar metabolites}

Chlorophylls and carotenoids were extracted with acetone/water $(80 / 20, v / v)$. Chlorophyll a $\left(\mathrm{Chl}_{\mathrm{a}}\right)$, chlorophyll b $\left(\mathrm{Chl}_{\mathrm{b}}\right)$, total chlorophyll $\left(\mathrm{Chl}_{(\mathrm{a}+\mathrm{b})}\right)$ and $\mathrm{Chl}_{\mathrm{a}} / \mathrm{Chl}_{\mathrm{b}}$ ratio were determined according to Arnon (1949) and Sesták et al. (1971) and total carotenoids (Car) according to Lichtenthaler (1987) and expressed as $\mathrm{mg} \mathrm{g}^{-1} \mathrm{DW}$. Total soluble sugars (TSS) were extracted according to Irigoyen et al. (1992), by heating the samples in ethanol/water $\left(80 / 20\right.$, v/v) during $1 \mathrm{~h}$, at $80^{\circ} \mathrm{C}$, and concentration was determined by the anthrone method and expressed as $\mathrm{mg}$ $\mathrm{g}^{-1} \mathrm{DW}$, using glucose as a standard. Total soluble proteins (TSP) were quantified using the method of Bradford (1976), using bovine serum albumin as a standard, and expressed as $\mathrm{mg} \mathrm{g}^{-1} \mathrm{DW}$. Then, total thiols (-SH) in TSP extract were assessed according to Ellman (1959), using an extinction coefficient of $13,600 \mathrm{M}^{-1} \mathrm{~cm}^{-1}$, and being expressed as $\mathrm{nM}$ $\mathrm{mg}^{-1} \mathrm{DW}$. To access the lipid peroxidation degree were quantified the thiobarbituric acid-reactive-substances (TBARS) following the method of Heat (1968), with adaptations from Hodges et al. (1999). The total of TBARS concentration was expressed in terms of $\mathrm{nmol} \mathrm{g}^{-1} \mathrm{DM}$, using an extinction coefficient of $157,000 \mathrm{M}^{-1} \mathrm{~cm}^{-1}$.

\subsection{Leaf minerals}

In the winter resting period, leaf samples were taken following the standard procedure for this species (Bryson et al., 2014). All tissue 
samples were dried at $70^{\circ} \mathrm{C}$, ground and analyzed for elemental composition. Tissue analyses were performed by Kjeldahl $(\mathrm{N})$, colorimetry (B and P), flame emission spectrometry (K) and atomic absorption spectrophotometry ( $\mathrm{Ca}, \mathrm{Mg}, \mathrm{Cu}, \mathrm{Fe}, \mathrm{Zn}$, and $\mathrm{Mn}$ ) methods (Walinga et al., 1989), after the samples being digested with nitric acid in a microwaves (MARSXpress CEM).

\subsection{Pruning wood, yield, fruit physical characteristics and maturation index}

Trees were pruned once, at the end of the second growing season, in the winter resting period, and pruning wood was used as an index of the tree's growth. A traditional hand-made pruning was performed by the same high experienced person in all the trees, having been removed the older lower and the crossed branches. Trees were harvested by using a tree shaking machine at the farmers' time and weighed separately per tree. The maturation index (MI) was determined according to the method proposed by Hermoso et al. (1991) and varied between 0 and 7. Olive fruits were classified into the following categories: 0 - olives with intense green epidermis; 1 - olives with yellowish green epidermis; 2 olives with red spots or areas in less than half of the fruit; 3 -olives with red or light violet epidermis over more than half of the fruit; 4 - olives with black epidermis and totally white pulp; 5 - olives with black epidermis and less than half purple pulp; 6 - olives with black epidermis and more than half purple pulp; 7 - olives with black epidermis and totally purple pulp. With a to $h$ being the number of fruits in each category, the MI was calculated as follows:

$\mathrm{MI}=(\mathrm{a} \times 0+\mathrm{b} \times 1+\mathrm{c} \times 2+\mathrm{d} \times 3+\mathrm{e} \times 4+\mathrm{f} \times 5+\mathrm{g} \times 6+\mathrm{h} \times 7) / 100$.

\subsection{Oil yield, extraction and quality analysis}

Oil yield was determined using a Soxhlet apparatus by extracting dry material with $40-60{ }^{\circ} \mathrm{C}$ petroleum ether. The olive oil used for the quality analyses was extracted within $24 \mathrm{~h}$ of the olive harvest. The oil was extracted by processing $15 \mathrm{~kg}$ of olives at about $25^{\circ} \mathrm{C}$ for $30 \mathrm{~min}$, using an olive oil extraction equipment (OLIOMIO 50, Toscana Enologica Mori, Tavarnelle Val di Pesa (FI), Italy). The oil collected was placed in dark glass bottles and kept at $4{ }^{\circ} \mathrm{C}$ for latter analysis.

The oil quality parameters were determined according to the European Community regulation EEC/2568/91(Regulation, 1991). Free acidity (FA) measures the hydrolytic breakdown of triglycerides to mono and di-glycerides, leading to fatty acid liberation. This variable is an indicator of the olive's quality, the procedures of harvesting, handling, transportation and storage prior to olive milling (Khaleghi et al., 2015). FA was expressed as \% oleic acid per $100 \mathrm{~g}$ oil. Peroxide index (PI), a measure of the active oxygen bound by the oil, which reflects the hydroxyperoxide value (Khaleghi et al., 2015), was expressed as $\mathrm{mg} \mathrm{EqO} \mathrm{kg}^{-1}$ oil. The ultraviolet spectrophotometric analysis gives indications about the oxidation stage of the olive oil. The extinctions at specified wavelengths, $232 \mathrm{~nm}\left(\mathrm{~K}_{232}\right)$ and $270 \mathrm{~nm}\left(\mathrm{~K}_{270}\right)$, are related with the formation of conjugated diene and triene compounds, respectively, due to oxidation (Khaleghi et al., 2015). $\Delta \mathrm{K}$ is the variation of the specific extinction.

\subsection{Statistical analysis}

Statistical calculations were performed using the software program SPSS for Windows (v. 22). Statistical differences $(P<0.05)$ were evaluated by Student's $t$-test.For statistical analysis of RWC, arcsine transformation was performed.

\section{Results}

\subsection{Leaf gas exchange and chlorophyll a fluorescence}

Overall, KL contributed to improve $\mathrm{A}, \mathrm{g}_{\mathrm{s}}$ and $\mathrm{E}$. The absence of significant influence was only recorded on July 20th 2016, during the morning period, and on July 21st, 2017, in both periods (Fig. 2). Moreover, the influence of KL was more evident in 2016 than in 2017, specially during July and August months. In addition, overall, KL improved $g_{s}$ to a higher extent than E. For instance, on August 3rd 2016, the increase of $\mathrm{g}_{\mathrm{s}}$ reached $83 \%$ and $129 \%$ during the morning and midday, against $65 \%$ and $81 \%$ on E, respectively, while on August 17th the increments were $126 \%$ and $173 \%$ on $g_{s}$, against $82 \%$ and $106 \%$ on $\mathrm{E}$, respectively. By other side, $\mathrm{C}_{\mathrm{i}} / \mathrm{C}_{\mathrm{a}}$ ratio and $\mathrm{A} / \mathrm{g}_{\mathrm{s}}$ were less affected by KL application (Fig. 2). KL decreased $\mathrm{C}_{\mathrm{i}} / \mathrm{C}_{\mathrm{a}}$ on July 20th and August 31st 2016, at midday, and on September 6th 2017 during the morning period, while enhanced $C_{i} / C_{a}$ ratio on August 17th 2016 during the morning. Meanwhile, $\mathrm{KL}$ improved $\mathrm{A} / \mathrm{g}_{\mathrm{s}}$ on July 20th and August $31 \mathrm{st}$ 2016, during midday, whereas decreased this ratio on August 17th and 31st 2016, during the morning periods.

The light response curve presented in Fig. $3 \mathrm{~A}$ revealed that under low light intensity $\left(0 \sim 200 \mu \mathrm{mol} \mathrm{m}^{-2} \mathrm{~s}^{-1}\right)$, the net photosynthetic rate of olive leaves increased almost linearly with the increase of light intensity, but the increase rate of control plants was slightly faster than that of kaolin treatment. Then, under medium light intensity (200 $800 \mu \mathrm{mol} \mathrm{m}^{-2} \mathrm{~s}^{-1}$ ), the net photosynthetic rate's increase of both treatments slowed down, presenting KL leaves higher value at the upper limit of PPFD. Under high light intensity $\left(1000 \mu \mathrm{mol} \mathrm{m}^{-2} \mathrm{~s}^{-1}\right.$ and above), KL plants maintained higher net photosynthesis than control ones, being evident a decrease of photosynthetic rate with the increase of light intensity, mainly in control treatment. Both the modified rectangular hyperbola (Fig. 3b) and the non-rectangular hyperbola (Fig. 3c) models fitted the light-response curves of photosynthetic rate well, but the modified rectangular hyperbola model was the best model in fitting the data. Under these circumstances, were observed significant lower light compensation point, apparent quantum yield and dark respiration, and higher light saturation point and maximum net photosynthetic rate in KL treatment (Table 2).

Kaolin affected chlorophyll $a$ fluorescence variables (Fig. 4) to a less extent than A and $g_{s}$ (Fig. 2). Nevertheless, a tendency exists to a better functioning of photosystem II (PSII) in kaolin-treated plants. On August 17th 2016, trees pulverised with $\mathrm{KL}$ had higher $\mathrm{F}_{\mathrm{v}} / \mathrm{F}_{\mathrm{m}}$ during the morning, on August 31st displayed superior Fv/Fm, ФPSII, $\mathrm{F}_{\mathrm{v}}$ '/ $/ \mathrm{F}_{\mathrm{m}}$ ' and ETR on both periods, and greater $\mathrm{qP}$ at midday, while on September 19th and October 11th KL-plants presented higher values of Fv' /Fm' and ETR during the morning. In 2017, KL-trees had higher values of ФPSII and ETR during the mornings of August 10th and September 6th (Fig. 4).

\subsection{Leaf water status, density and metabolites}

Fig. 5 shows the evolution of leaf RWC and leaf density. Overall, RWC increased by KL application, although no significant differences were recorded on July 20th and September 19th of 2016 and on July 21st and September 6th of 2017. Leaf density of both C and KL plants raised across the summer months of 2016 and 2017, being lower in KL sprayed leaves at the end of the season.

Leaf metabolites were little affected by KL application, as no significant differences were verified on TSS, $\mathrm{Chl}_{(\mathrm{a}+\mathrm{b})}, \mathrm{Chl}_{\mathrm{a} / \mathrm{b}}, \mathrm{Car}, \mathrm{Chl}_{(\mathrm{a}+\mathrm{b})} / \mathrm{Car}$ and -SH concentrations (Table 3). The exceptions were recorded for TSP and TBARS concentrations, which were lower in KL leaves (Table 3).

\subsection{Leaf minerals}

The application of kaolin influenced leaf mineral status (Fig. 6), mainly in the first growing season, being macronutrients more affected than micronutrients. In 2017 was observed an increment of N, P and Zn 


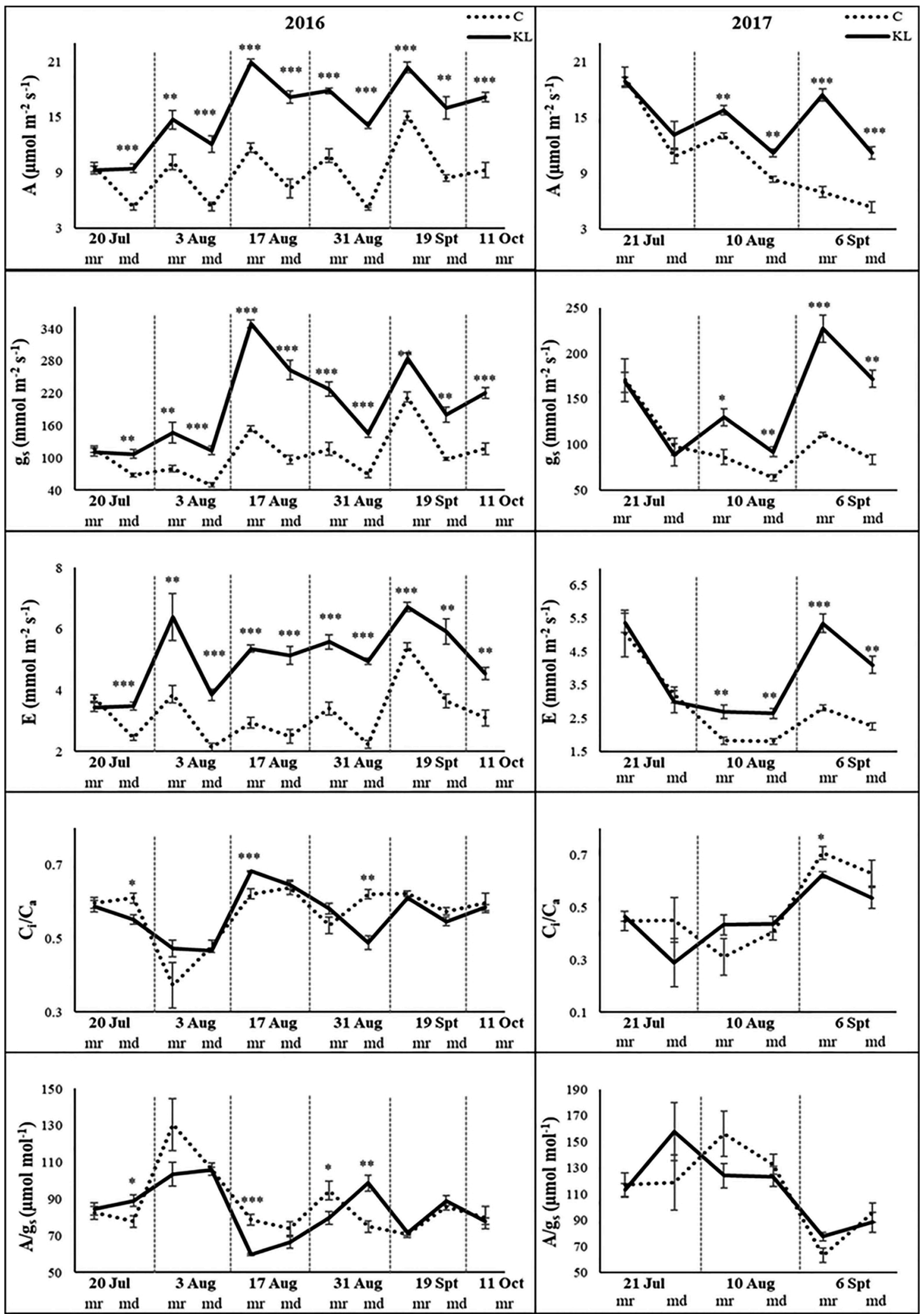

Fig. 2. Evolution of leaf gas exchange variables in control plants (C) and sprayed with kaolin (KL) during the morning (mr) and midday (md) periods of 2016 and 2017. Net photosynthetic rate $(\mathrm{A})$, stomatal conductance $\left(\mathrm{g}_{\mathrm{s}}\right)$, transpiration rate $(\mathrm{E})$, ratio of intercellular to atmospheric $\mathrm{CO}_{2}$ concentration $\left(\mathrm{C}_{\mathrm{i}} / \mathrm{C}_{\mathrm{a}}\right)$ and intrinsic water use efficiency $\left(\mathrm{A} / \mathrm{g}_{\mathrm{s}}\right)$. Values are means $\pm \mathrm{SE}$. Significance: ${ }^{*} \mathrm{P}<0.05, * * \mathrm{P}<0.01,{ }^{* * *} \mathrm{P}<0.001$. 


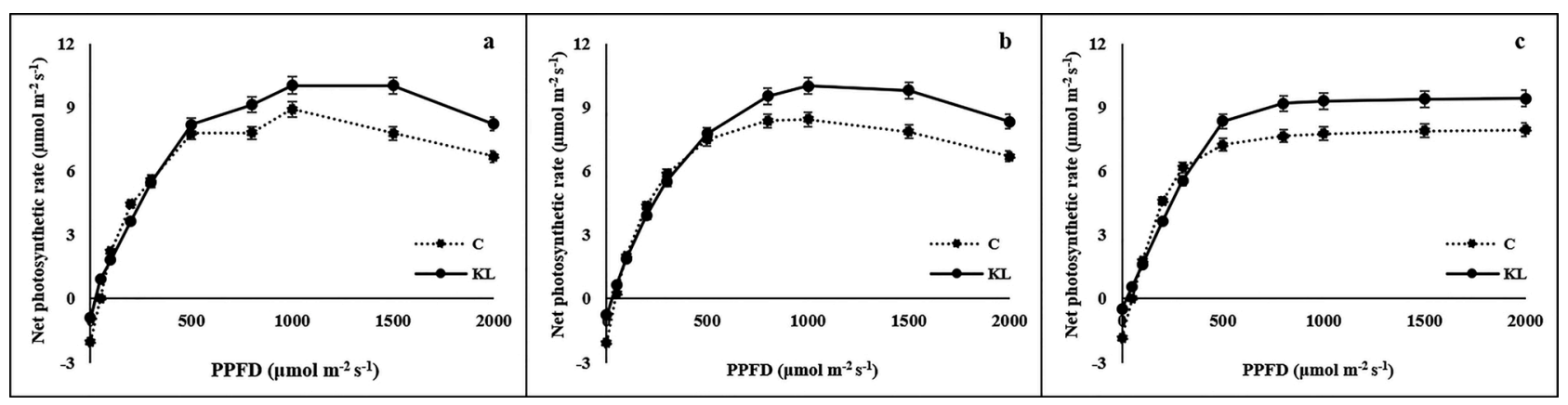

Fig. 3. Photosynthetic light responses (a) and simulation of A-PPFD curves of control (C) and kaolin (KL) plants by the modified rectangular hyperbola (b) and nonrectangular hyperbola (c) models.

Table 2

Light compensation point (LCP, $\mu$ mol photon $\left.\mathrm{m}^{-2} \mathrm{~s}^{-1}\right)$, light saturation point (LSP, $\mu \mathrm{mol}$ photon $\left.\mathrm{m}^{-2} \mathrm{~s}^{-1}\right)$, apparent quantum yield $\left(\varphi, \mu \mathrm{mol}\left(\mathrm{CO} \mathrm{O}_{2}\right) \mu \mathrm{mol}(\mathrm{photon})^{-1}\right)$, maximum net photosynthetic rate $\left(\mathrm{A}_{\max }, \mu \mathrm{mol} \mathrm{CO} \mathrm{CO}_{2} \mathrm{~m}^{-1}\right.$ ) and dark respiration (Rd, $\mu$ mol $\mathrm{CO}_{2} \mathrm{~m}^{-2} \mathrm{~s}^{-1}$ ) of control (C) and kaolin (KL) trees fitted by the modified rectangular hyperbola and non-rectangular hyperbola models.

\begin{tabular}{|c|c|c|c|c|c|c|}
\hline & \multicolumn{2}{|c|}{ Modified rectangular hyperbola model } & \multirow{2}{*}{ Sig. } & \multicolumn{2}{|c|}{ Non-rectangular hyperbola model } & \multirow{2}{*}{ Sig. } \\
\hline & $\mathrm{C}$ & KL & & $\mathrm{C}$ & KL & \\
\hline LCP & $43.6 \pm 1.31$ & $26.5 \pm 1.46$ & $* *$ & $49.1 \pm 2.94$ & $22.3 \pm 0.67$ & $* * *$ \\
\hline LSP & $593 \pm 24$ & $808 \pm 56$ & ** & $608 \pm 27$ & $693 \pm 35$ & $*$ \\
\hline$\varphi$ & $0.027 \pm 0.001$ & $0.022 \pm 0.001$ & * & $0.031 \pm 0.001$ & $0.020 \pm 0.001$ & $* *$ \\
\hline$A_{\max }$ & $7.90 \pm 0.39$ & $9.62 \pm 0.29$ & * & $7.53 \pm 0.43$ & $9.11 \pm 0.27$ & * \\
\hline Rd & $2.14 \pm 0.085$ & $0.806 \pm 0.036$ & $* *$ & $1.81 \pm 0.07$ & $0.513 \pm 0.032$ & $* *$ \\
\hline
\end{tabular}

Values are means $\pm \mathrm{SE} .{ }^{*} \mathrm{P}<0.05 ; * * \mathrm{P}<0.01$

and decreases of $\mathrm{K}, \mathrm{Mg}$ and $\mathrm{Mn}$ concentrations on $\mathrm{KL}$ trees, while no significant influence was noticed on Ca, B, Cu and Fe. In 2018, KL plants presented higher concentration of $\mathrm{Ca}$, lower values of $\mathrm{K}$ and $\mathrm{Mn}$, as in 2017, whereas no significant differences were recorded in the other elements (Fig. 6).

\subsection{Pruning wood, yield, maturation index and fruit and oil characteristics}

After two growing seasons, kaolin increased the pruning wood by 75 $\%$ (Table 4). In addition, kaolin improved crop yield by $65.8 \%$ and 79.2 $\%$ in 2016 and 2017, respectively (Table 4). Mean fruit weight, both as fresh and dry mass, and pulp/stone ratio were also enhanced by KL application in both years (Table 4). Regarding maturation index, no significant differences were recorded between treatments (Table 4). Oil analysis performed in 2017 revealed that kaolin also ameliorates the oil yield and its quality, by reducing PI and $\mathrm{K}_{232}$ coefficient. By other side, no significant differences were recorded in $\mathrm{K}_{270}, \Delta \mathrm{K}$ and FA (Table 4).

\section{Discussion}

\subsection{Kaolin improves olive trees physiological performance under a deficit irrigation strategy}

Kaolin improved olive tree $\mathrm{CO}_{2}$ assimilation by reducing the stomatal limitations. The expected reduction in sprayed organs temperature, as observed in some studies (Segura-Monroy et al., 2015; Dinis et al., 2018), might reduce the leaf-to-air vapor pressure deficit (Jifon and Syvertsen, 2003) and, consequently, the driving force for transpiration, promoting an increase of $g_{s}$ (Zhang et al., 2017). This response comes in agreement with previous works (Jifon and Syvertsen, 2003; Denaxa et al., 2012; Boari et al., 2015; Nanos, 2015; Brito et al., 2018c, 2019b).

It is also commonly described that kaolin alleviates the non-stomatal limitations to photosynthesis, due to the preservation of the photosynthetic machinery integrity, especially under rainfed conditions and severe stress periods (Jifon and Syvertsen, 2003; Correia et al., 2014; Segura-Monroy et al., 2015; Brito et al., 2018c, 2019b; Dinis et al., 2018). In fact, the conjugation of $g_{s}$ and $C_{i} / C_{a}$ data supports this assumption, as intercellular $\mathrm{CO}_{2}$ concentration values did not present any association with $g_{s}$. Nevertheless, $C_{i}$ values should be treated with some caution, due to the non-uniform aperture of stomata over the leaf surface (patchiness). Under stress conditions, the $\mathrm{C}_{\mathrm{i}}$ calculated from gas exchange measurements can be overestimated and lead to erroneous conclusions of non-stomatal limitations to photosynthesis (Downton et al., 1988). However, our analysis is based on the hypothesis that patchy stomatal closure did not occur in mature olive leaves (Nogués and Baker, 2000). Moreover, the analysis of chlorophyll $a$ fluorescence variables also revealed lower perturbations in photochemical reactions of KL plants. The higher $\Phi P S I I$ indicates that kaolin increases the proportion of absorbed light that is used in photochemistry (Maxwell and Johnson, 2000), being this response mainly due to a higher capture of excitation energy by the open PSII centers $\left(\mathrm{F}_{\mathrm{v}}\right.$ ' $/ \mathrm{F}_{\mathrm{m}}$ '), than by changes in its proportion (qP) (Baker, 2008). Similar behaviour was previously shown by Brito et al. (2018c, 2019b) in droughted olive trees. Furthermore, kaolin improved the linear electron flow through the PSII (ETR) and the sensitive stress indicator, Fv/Fm ratio, i.e. the maximum quantum efficiency of PSII (Maxwell and Johnson, 2000). A positive kaolin influence on the light-dependent reactions of photosynthesis was also described in other studies (Jifon and Syvertsen, 2003; Segura-Monroy et al., 2015; Brito et al., 2018c).

The results obtained from light response curves (Fig. 3, Table 2), at high light levels $\left(>800 \mu \mathrm{mol} \mathrm{m}^{-2} \mathrm{~s}^{-1}\right.$ ), corroborate the photosynthesis data obtained from gas exchange and fluorescence measurements, as KL trees presented higher Amax and LSP, confirming the better adaptability of these plants to high PPFD. Thus, we may assume that factors such as stomatal resistance, electron transport reactions, RuBP regeneration, RuBisCO activity and/or metabolism of triose phosphates have become less limiting in plants treated with KL foliar spray. Conversely, the application of KL decreased the $\varphi$, indicating that KL trees had lower acclimation capacity to low light conditions. This response was corroborated by previous studies of Brito et al. (2018c) that showed a 


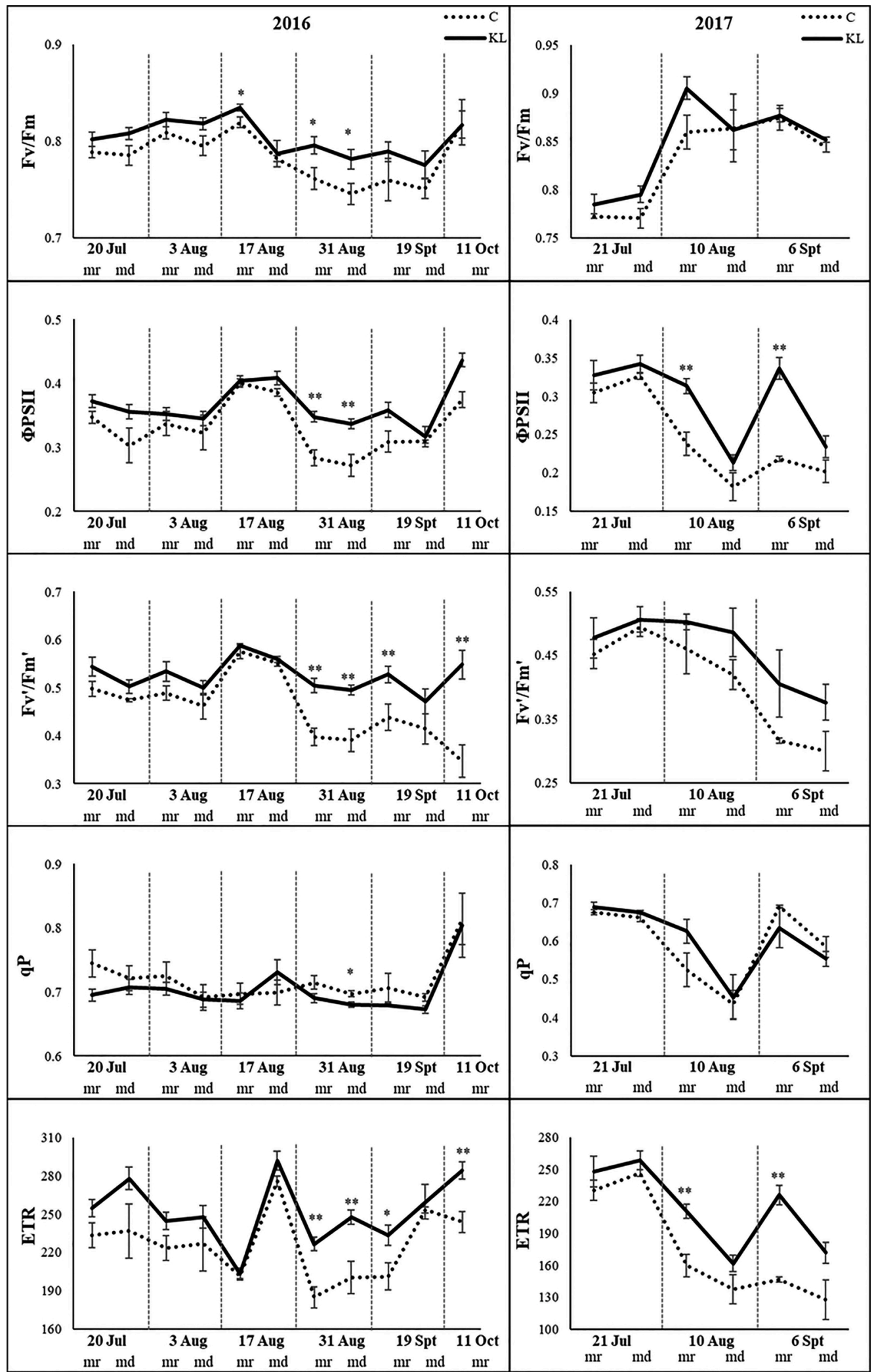

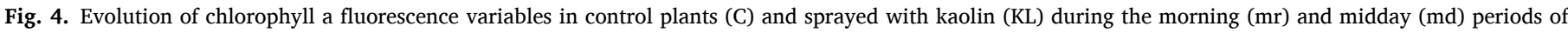

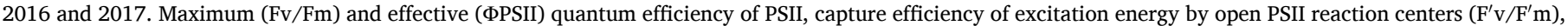
photochemical quenching (qP) and electron transport rate (ETR, $\mu \mathrm{mol} \mathrm{e}^{-} \mathrm{m}^{-2} \mathrm{~s}^{-1}$ ). Values are means $\pm \mathrm{SE}$. Significance: ${ }^{*} \mathrm{P}<0.05, * * \mathrm{P}<0.01, * * * \mathrm{P}<0.001$. 


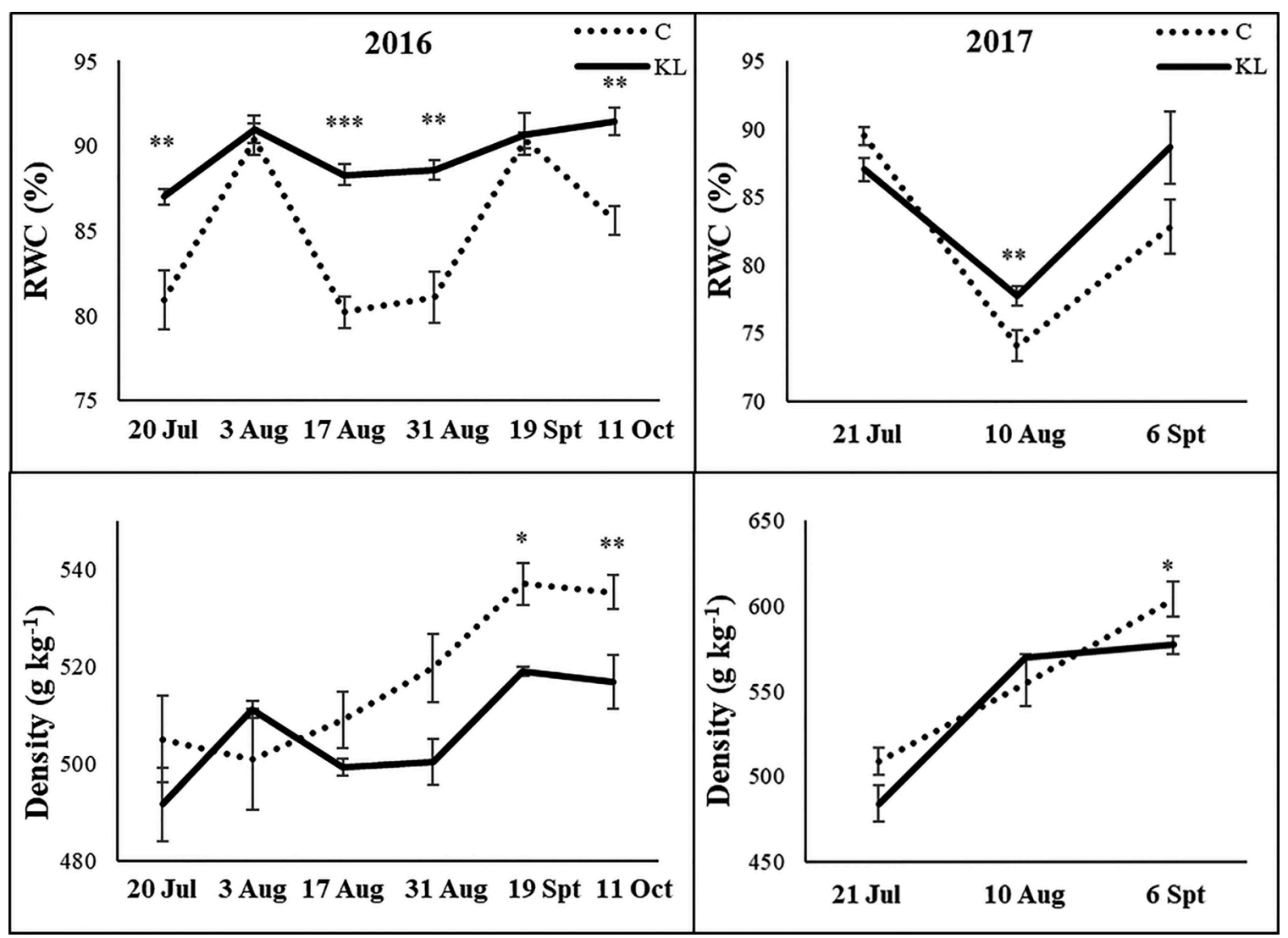

Fig. 5. Evolution of leaf relative water content (RWC) and leaf density in control plants (C) and sprayed with kaolin (KL) in 2016 and 2017 . Values are means \pm SE. Significance: $* * \mathrm{P}<0.01, * * * \mathrm{P}<0.001$.

Table 3

Leaf metabolic analyses of control (C) and kaolin (KL) plants in 2016 and 2017. Total soluble sugars (TSS), total chlorophylls $\left(\mathrm{Chl}_{(\mathrm{a}+\mathrm{b})}\right)$, chlorophyll a/b ratio $\left(\mathrm{Chl}_{\mathrm{a} / \mathrm{b}}\right)$, total carotenoids (Car), $\mathrm{Chl}_{(\mathrm{a}+\mathrm{b})} /$ Car ratio, total soluble proteins (TSP), total phenolic compounds (TPC, $\left.\mathrm{mg} \mathrm{g}^{-1} \mathrm{DW}\right)$, total thiols (-SH) and TBARS concentrations.

\begin{tabular}{|c|c|c|c|c|}
\hline & & $\mathrm{C}$ & $\mathrm{KL}$ & Sig. \\
\hline \multirow{2}{*}{ TSS (mg g $\left.{ }^{-1} \mathrm{DW}\right)$} & 2016 & $110.4 \pm 3.5$ & $95.9 \pm 5.7$ & $\mathrm{~ns}$ \\
\hline & 2017 & $133.6 \pm 2.9$ & $133.0 \pm 1.7$ & ns \\
\hline \multirow{2}{*}{$\operatorname{Chl}_{(\mathrm{a}+\mathrm{b})}\left(\mathrm{mg} \mathrm{g}^{-1}{ }_{\mathrm{DW}}\right)$} & 2016 & $2.26 \pm 0.24$ & $2.65 \pm 0.11$ & ns \\
\hline & 2017 & $2.15 \pm 0.10$ & $2.12 \pm 0.18$ & ns \\
\hline \multirow{2}{*}{$\mathrm{Chl}_{\mathrm{a} / \mathrm{b}}$} & 2016 & $2.59 \pm 0.08$ & $2.62 \pm 0.05$ & $\mathrm{~ns}$ \\
\hline & 2017 & $2.59 \pm 0.01$ & $2.48 \pm 0.23$ & $\mathrm{~ns}$ \\
\hline \multirow{2}{*}{ Car $\left(\mathrm{mg} \mathrm{g}^{-1} \mathrm{DW}\right)$} & 2016 & $0.544 \pm 0.061$ & $0.610 \pm 0.016$ & $\mathrm{~ns}$ \\
\hline & 2017 & $0.587 \pm 0.018$ & $0.539 \pm 0.040$ & ns \\
\hline \multirow{2}{*}{$\operatorname{Chl}_{(\mathbf{a}+\mathbf{b})} / \mathrm{Car}$} & 2016 & $4.17 \pm 0.09$ & $4.34 \pm 0.09$ & $\mathrm{~ns}$ \\
\hline & 2017 & $3.67 \pm 0.09$ & $4.02 \pm 0.61$ & $\mathrm{~ns}$ \\
\hline \multirow{2}{*}{ TSP (mg g ${ }^{-1}$ DW) } & 2016 & $4.44 \pm 0.70$ & $2.65 \pm 0.16$ & $*$ \\
\hline & 2017 & $4.34 \pm 0.35$ & $3.01 \pm 0.21$ & * \\
\hline \multirow{2}{*}{$-\mathrm{SH}\left(\mathrm{nmol} \mathrm{mg}{ }_{\mathrm{DW}}^{-1}\right)$} & 2016 & $0.807 \pm 0.105$ & $0.623 \pm 0.048$ & ns \\
\hline & 2017 & $0.730 \pm 0.071$ & $0.785 \pm 0.135$ & ns \\
\hline \multirow{2}{*}{ TBARS (nmol g ${ }^{-1}$ DW) } & 2016 & $156.9 \pm 18.2$ & $87.9 \pm 6.3$ & $* *$ \\
\hline & 2017 & $160.5 \pm 8.2$ & $84.8 \pm 4.5$ & $* *$ \\
\hline
\end{tabular}

Values are means \pm SE. ns $-\mathrm{P}>0.05,{ }^{*} \mathrm{P}<0.05,{ }^{* *} \mathrm{P}<0.01$.

loss of KL effectiveness under low PPFD, and Denaxa et al. (2012) that displayed KL limitation to photosynthesis during daytime periods of low light intensity, while no such effects were recorded at midday hours. Meanwhile, the lower LCP of KL-sprayed leaves may help to maintain a positive carbon balance under low light levels, while the inferior Rd can ensure faster dry matter accumulation. Interestingly, low dark respiration rate and small light compensation point are well-known attributes of shade tolerance. Shade-related characteristics were also reported previously in response to kaolin application (Brito et al., 2018c, 2019b; Denaxa et al., 2012; Nanos, 2015; Segura-Monroy et al., 2015).

Despite the higher $\mathrm{g}_{\mathrm{s}}$ and $\mathrm{E}$ rate, $\mathrm{KL}$ - pulverised trees generally exhibited superior RWC values, possibly by the reduction in the driving force for transpiration, discussed previously. The improvement of water status by kaolin application is commonly described on the literature (Boari et al., 2015; Denaxa et al., 2012; Nanos, 2015; Brito et al., 2018c, 2019b). By improving water status and sustaining leaf turgidity, KL-trees were able to maintain the $\mathrm{g}_{\mathrm{s}}$ rates and to keep the photosynthetic machinery to work more efficiently. In control plants, the restauration of RWC values to KL levels on August $3^{\text {rd }}$ and on September 19th 2016 might be due to rainfall events that occurred on the previous days. In 2017, as drought was more severe, kaolin influence on RWC was only felt in the most severe period analysed. On the other hand, in response to the better water status experienced by KL-trees and the shade effect caused by the kaolin (Gregoriou et al., 2007), the leaf density of KL-trees was lower at the end of summer. These results corroborate the findings of Denaxa et al. (2012); Nanos (2015) and Brito et al. (2018c, 2019b), that showed not only a reduction in leaf density but also the development of shade-related leaf anatomical features.

Interestingly, the application of KL reduced the concentration of TBARS in leaves, which result from the in vitro reaction between tiobarbituric acid and malondialdehyde. In its turn, malondialdehyde is a secondary end product of the oxidation of polyunsaturated fatty acids, being a useful index of general lipid peroxidation (Hodges et al., 1999), the most obvious signal of oxidative stress in plants. Lower oxidative damage after kaolin application was reported previously by the reduction of ROS accumulation (Dinis et al., 2016), lipid peroxidation (Bernardo et al., 2017) and electrolyte leakage (Brito et al., 2018c). According to specific cellular metabolic circumstances and repair capacities, cells respond to lipid peroxidation by promoting cell survival or induce cell death (Ayala et al., 2014). The higher concentration of 


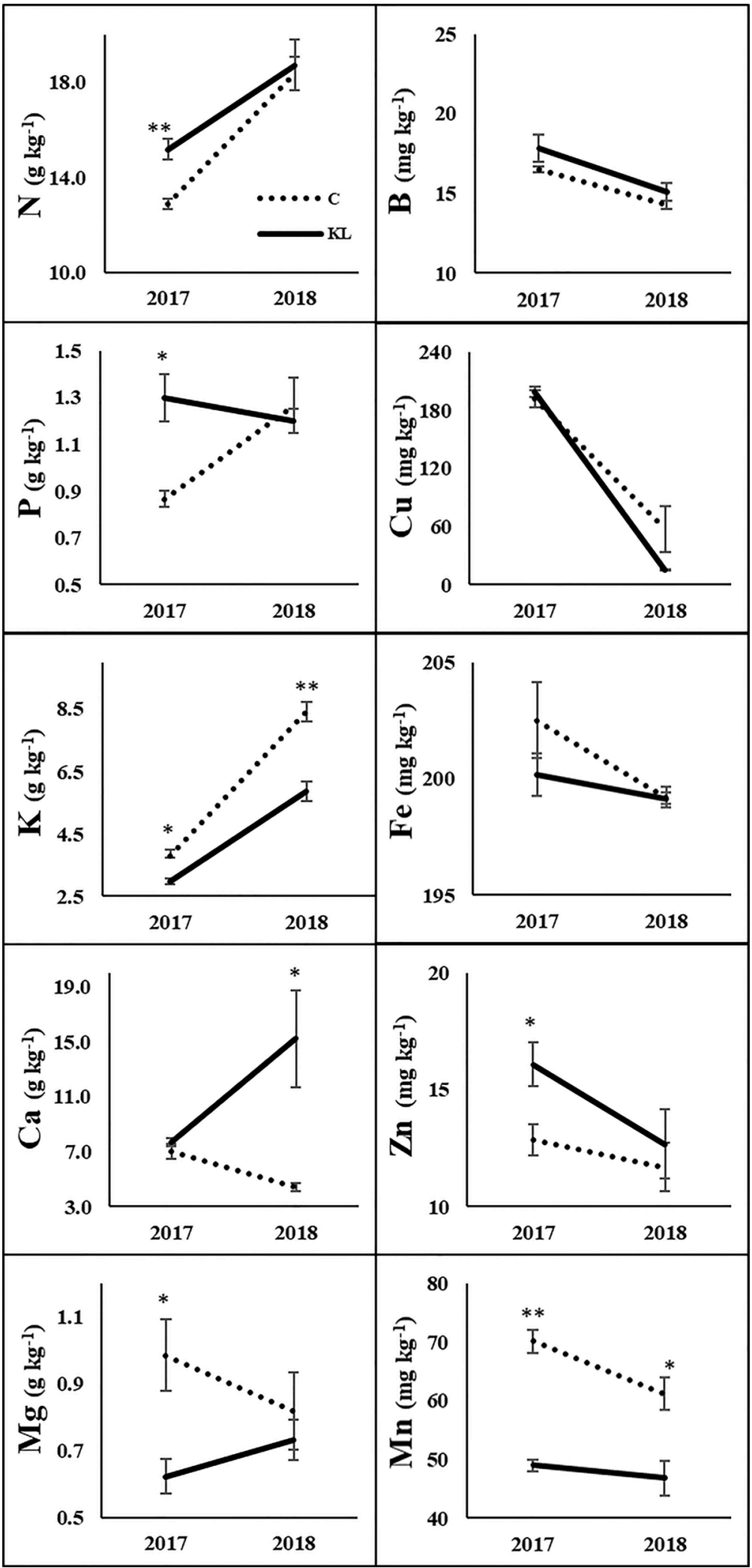

Fig. 6. Concentration of macronutrients ( $\mathrm{P}, \mathrm{P}, \mathrm{K}, \mathrm{Ca}, \mathrm{Mg}, \mathrm{g} \mathrm{kg}^{-1}$ ) and micronutrients (B, Cu, Fe, Zn, Mn, mg kg ${ }^{-1} \mathrm{DW}$ ) in leaves of control (C) and kaolin (KL) plants (January 2017 and January 2018).

soluble proteins in $\mathrm{C}$ plants might indicate that non-treated trees are responding to the increased lipid peroxidation by the activation of signalling pathways that upregulate antioxidants proteins, resulting in an adaptive stress response that is only possible under subtoxic conditions
(Ayala et al., 2014). Thus, our results indicate that trees are under low to moderate stress conditions and still capable to increase their defences, although at the expense of investing photoassimilates in growth and yield. However, under severe environmental conditions, KL was shown 
Table 4

Trees pruning wood (PW), crop yield, fruit weight, fruit pulp/stone ratio and fruit maturation index (MI) in 2016 and 2017, and olive oil yield and quality indices in (peroxide index - PI; free acidity - FA; K2 32 - specific extinction at wavelength $232 ; \mathrm{K}_{270}$ - specific extinction at wavelength $270 ; \Delta \mathrm{K}$ - variation of the specific extinction) in 2017 of control (C) and kaolin (KL) trees.

\begin{tabular}{|c|c|c|c|c|}
\hline & & $\mathrm{C}$ & KL & Sig. \\
\hline PW $\left(\mathrm{kg}\right.$ tree $\left.^{-1}\right)$ & 2017 & $1.02 \pm 0.21$ & $1.79 \pm 0.15$ & $*$ \\
\hline \multirow{2}{*}{ Yield (kg tree ${ }^{-1}$ ) } & 2016 & $3.77 \pm 0.70$ & $6.25 \pm 1.10$ & + \\
\hline & 2017 & $3.80 \pm 0.76$ & $6.81 \pm 0.40$ & * \\
\hline \multirow{2}{*}{ Fruit $_{(\mathrm{gFW})}$} & 2016 & $3.08 \pm 0.14$ & $4.39 \pm 0.12$ & $* * *$ \\
\hline & 2017 & $2.61 \pm 0.05$ & $3.11 \pm 0.07$ & $* * *$ \\
\hline \multirow{2}{*}{ Fruit $\left(g_{D W}\right)$} & 2016 & $1.22 \pm 0.05$ & $1.67 \pm 0.04$ & $* * *$ \\
\hline & 2017 & $1.08 \pm 0.02$ & $1.44 \pm 0.03$ & $* * *$ \\
\hline \multirow{2}{*}{ Pulp/Stone } & 2016 & $3.34 \pm 0.07$ & $3.83 \pm 0.09$ & $* * *$ \\
\hline & 2017 & $3.10 \pm 0.07$ & $4.17 \pm 0.08$ & $* * *$ \\
\hline \multirow{2}{*}{ MI } & 2016 & $3.17 \pm 0.03$ & $3.33 \pm 0.07$ & ns \\
\hline & 2017 & $1.77 \pm 0.12$ & $1.60 \pm 0.15$ & $\mathrm{~ns}$ \\
\hline Oil yield (\%) & 2017 & $13.9 \pm 0.38$ & $16.9 \pm 0.50$ & * \\
\hline PI ${ }_{(\mathrm{mgEq}}^{-1} \mathrm{O} 2 \mathrm{~kg}$ oil) & 2017 & $15.1 \pm 0.09$ & $8.83 \pm 0.009$ & $* * *$ \\
\hline FA ${ }_{(\% \text { oleic acid) }}$ & 2017 & $0.117 \pm 0.011$ & $0.111 \pm 0.001$ & $\mathrm{~ns}$ \\
\hline $\mathrm{K}_{232}$ & 2017 & $1.89 \pm 0.10$ & $1.23 \pm 0.17$ & $*$ \\
\hline$K_{270}$ & 2017 & $0.107 \pm 0.004$ & $0.103 \pm 0.006$ & $\mathrm{~ns}$ \\
\hline$\Delta \mathrm{K}$ & 2017 & $0.005 \pm 0.000$ & $0.005 \pm 0.001$ & $\mathrm{~ns}$ \\
\hline
\end{tabular}

Values are means \pm SE. ns $-\mathrm{P}>0.05,+0.1>\mathrm{P}>0.05,{ }^{*} \mathrm{P}<0.05, * * * \mathrm{P}<0.001$

to avoid the degradation of soluble proteins (Brito et al., 2018c, 2019b, Dinis et al., 2018).

\subsection{Kaolin improved tree growth, crop yield, and oil yield and quality}

In response to the better physiological performance and the reduced necessity to invest in antioxidant defences, KL- pulverised trees were able to canalize the photosynthates to increase crop and oil yield. The higher olive yield promoted by kaolin agrees with previous studies in different plant species, including olive tree (Saour and Makee, 2003; Correia et al., 2014; Segura-Monroy et al., 2015; AbdAllah, 2019; Brito et al., 2018d). However, a decrease (Cantore et al., 2009) or the absence of influence (Nanos, 2015; AbdAllah, 2019) were also recorded, especially under optimum water conditions or severe stress conditions, respectively. The higher productivity promoted by the kaolin application was accompanied by the increase in fruits fresh and dry weight and pulp/stone ratio.

Although the net photosynthetic rate of olive trees was more benefited by kaolin application in 2016 than in 2017, the effects on fruit production was more notorious in 2017 than in 2016, probably because in a less dry year (2016) olive trees might increase the allocation of assimilates to vegetative growth. The highest pruning wood weight verified in KL plants confirms the greatest tree growth, as in other studies (Roussos et al., 2010; Segura-Monroy et al., 2015; Brito et al., 2019b). Moreover, assuming the higher vegetative growth in 2016 in KL trees, greater number of fruits were observed in 2017 (mean values of 2190 fruits/tree in KL and 1456 in control plants against 1423 and 1224, respectively, in 2016), contributing to higher yield. Therefore, the fruits harvested in 2017 were lighter than in 2016 and exhibited lower maturation index, typical responses of higher crop loads (Barone et al., 1994). Furthermore, the higher fruit dry mass and pulpe/stone ratio of KL-trees in 2017 were associated with the higher oil yield. The increase in fruit dry matter and oil yield were also reported by Saour and Makee (2003), while no influence was recorded by Nanos (2015). To notice, the oil yield recorded in this study (13.9-16.9\%) was below the average established yield for the studied cultivar (18-22\%) (Cordeiro et al., 2013), reflecting the option of the farmer to produce an olive oil richer in antioxidant properties in detriment of the full oil yield.

It is known that nutrients accumulation and distribution in plants is selective, being dependent on where and how nutrients are used by the plant in response to different conditions (McGrath and Lobell, 2013; Brito et al., 2019d). In the winter resting period, the nutritional status of leaves reflects the competition between fruits and leaves, but is also influenced by the preceding period of substantial water shortage, as the analyzed leaves grown during summer and early autumn (Arrobas et al., 2010). The higher N, P and Zn concentrations recorded in 2017 in KL-leaves, could be, in part, promoted by the water movement associated with higher $g_{s}$ and might be a requisite due to the superior photosynthetic activity of those plants. In fact, $\mathrm{N}, \mathrm{P}$ and $\mathrm{Zn}$ are greatly important in photosynthetic processes, and $\mathrm{P}$ in the store and transference of energy and carbohydrates (Hu and Schmidhalter, 2005; Tsonev and Lidon, 2012). Meanwhile, the loss of significant differences in the concentrations of these minerals in 2018 could be due to the dilution effect promoted by the higher vegetative growth in KL plants. Interestingly, in line with the better water status, reduced oxidative stress and higher yields, KL pulverised leaves consistently showed reduced concentrations of both $\mathrm{K}$ and $\mathrm{Mn}$ over the two growing seasons. $\mathrm{K}$ is involved in important biochemical and physiological processes, such as osmoregulation ( $\mathrm{Hu}$ and Schmidhalter, 2005), reflecting a reduced necessity of KL-plants to invest in osmotic adjustment. Moreover, olive fruits are important sinks of $\mathrm{K}$, may reaching $40 \%$ of total $\mathrm{K}$ (Rodrigues et al., 2012). At the same time, the lower Mn concentration might be linked to lower requirements on defence mechanisms, as Mn plays an important role in redox reactions, mainly as enzymatic co-factor, including in an important antioxidant enzyme, superoxide dismutase (Ciríaco da Silva et al., 2011).

The oil from KL-trees exhibited a PI $42 \%$ lower than C trees, showing a lower degradation of the oil due to oxidation (Khaleghi et al., 2015), which agree with the findings of Saour and Makee (2003); Khaleghi et al. (2015) and Nanos (2015). By other side, Brito et al. (2018d) found no influence of $\mathrm{KL}$ in this quality parameter. The determination of $\mathrm{K}_{232}$ and $\mathrm{K}_{270}$ are also useful for estimating the oxidation stage of olive oil, since are related with the formation of conjugated diene and triene in the oil, respectively, due to oxidation (Khaleghi et al., 2015). The lower $\mathrm{K}_{232}$ observed in the oils form KL-trees corroborate the findings of Saour and Makee (2003) and Khaleghi et al. (2015), that also reported the decrease of $\mathrm{K}_{270}$. Conversely, Brito et al. (2018d) only found a reduction in $K_{270}$ coefficient. Overall, we can assume that kaolin increases the oxidative stability of the oils. By other side, no changes were induced in FA, in line with the findings of Saour and Makee (2003) and Brito et al. (2018d), showing that olives quality prior to olive milling were similar in both treatments (Khaleghi et al., 2015). On the other hand, Khaleghi et al. (2015) and Nanos (2015) reported a reduction in FA with the application of kaolin. According to the European Community EEC/2568/91 (Regulation, 1991) the evaluated indices of the analyzed olive oils fall within the ranges established for "extra virgin olive oil" category.

\section{Conclusions}

Kaolin improved photosynthetic efficiency at high light intensity by reducing the stomatal limitations during all the summer season and the non-stomatal limitations during the most stressful periods. These responses were associated with better water status, which improved the capacity to maintain the stomatal conductance and the cellular metabolic functions and, reduced the oxidative damage. Nonetheless, KLtreated leaves had lower apparent quantum yield, justifying the adoption of some attributes of shade tolerance, as reduced leaf density, light compensation point and dark respiration rate. The amelioration of physiological and metabolic functions and the lower allocation of resources to summer stress tolerance mechanisms, allowed the KL-sprayed trees to increase the productivity, the oil yield and its oxidative stability.

Although the kaolin effectiveness on olive tree physiology was more robust in the wetter year, the applied sustained deficit irrigation strategy was enough to keep the irrigated trees under a low to moderate stressful stage, creating good conditions for kaolin action as stress alleviation product. Thus, the artificial reduction of summer stress by kaolin application had a positive synergistic effect with SDI which is especially 
relevant in some semi-arid areas where water available for irrigation do not cover all the necessities.

\section{CRediT authorship contribution statement}

Cátia Brito: Investigation, Formal analysis, Writing - original draft, Visualization. Alexandre Gonçalves: Investigation. Ermelinda Silva: Investigation. Sandra Martins: Investigation. Luís Pinto: Investigation. Luís Rocha: Investigation. Margarida Arrobas: Investigation, Writing review \& editing. Manuel Ângelo Rodrigues: Investigation, Writing review \& editing. José Moutinho-Pereira: Investigation, Writing - review \& editing. Carlos M. Correia: Conceptualization, Investigation, Writing - review \& editing, Supervision.

\section{Declaration of Competing Interest}

The authors declare that they have no known competing financial interests or personal relationships that could have appeared to influence the work reported in this paper.

\section{Acknowledgments}

This work was financed by project Interact: Integrative Research in Environment, Agro-Chain, and Technology, operation NORTE-01-0145FEDER-000017, research line ISAC, co-funded by European Regional Development Fund (FEDER) through NORTE 2020 (Programa Operacional Regional do Norte 2014/2020), and supported by the project "Novas práticas em olivais de sequeiro: estratégias de mitigação e adaptação às alterações climáticas”, PDR2020-101-032119, financed by the European Agricultural Fund for Rural Development (EAFRD) and the Portuguese State under Ação 1.1 "Grupos Operacionais", integrada na Medida 1. "Inovação" do PDR 2020: Programa de Desenvolvimento Rural do Continente. Institution. This work is supported by National Funds by FCT-Portuguese Foundation for Science and Technology, under the project UIDB/04033/2020. The authors are also grateful to the Foundation for Science and Technology (FCT, Portugal) for financial support by national funds FCT/MCTES to CIMO (UIDB/00690/2020).

\section{References}

AbdAllah, A., 2019. Impacts of kaolin and pinoline foliar application on growth, yield and water use efficiency of tomato (Solanum lycopersicum L.) grown under water deficit: a comparative study. J. Saudi Soc. Agric. Sci. 18, 256-268. https://doi.org/ 10.1016/j.jssas.2017.08.001.

Arnon, D.I., 1949. Copper enzymes in isolated chloroplasts. Polyphenoloxidase in Beta vulgaris. Plant Physiol. 24, 1-15. https://doi.org/10.1104/pp.24.1.1.

Arrobas, M.P., Lopes, J.I., Pavão, F.M., Cabanas, J.E., Rodrigues, M.Â., 2010. Comparative boron nutritional diagnosis for olive based on july and january leaf samplings. Commun. Soil Sci. Plant Anal. 41 (709), 720. https://doi.org/10.1080/ 00103620903563949.

Ayala, A., Muñoz, M.F., Argüelles, S., 2014. Lipid peroxidation: production, metabolism, and signaling mechanisms of malondialdehyde and 4-hydroxy-2-nonenal. Oxid. Med. Cell. Longev. 360438, 1-31. https://doi.org/10.1155/2014/360438.

Bacelar, E.A., Santos, D.L., Moutinho-Pereira, J.M., Lopes, J.I., Gonçalves, B.C., Ferreira, T.C., Correia, C.M., 2007. Physiological behaviour, oxidative damage and antioxidative protection of olive trees grown under different irrigation regimes. Plant Soil 292, 1-12. https://doi.org/10.1007/s11104-006-9088-1.

Baker, N.R., 2008. Chlorophyll fluorescence: a probe of photosynthesis in vivo. Annu. Ver. Plant Biol. 59, 89-113. https://doi.org/10.1146/annurev. arplant.59.032607.092759.

Barone, E., Gullo, G., Zappia, R., Inglese, P., 1994. Effect of crop load on fruit ripening and olive oil (Olea europea L.) quality. J. Hortic. Sci. 69, 67-73. https://doi.org/ 10.1080/14620316.1994.11515250.

Bernardo, S., Dinis, L.T., Luzio, A., Pinto, G., Meijón, M., Valledor, L., Conde, A. Gerós, H., Correia, C.M., Moutinho-Pereira, J., 2017. Kaolin particle film application lowers oxidative damage and DNA methylation on grapevine (Vitis vinifera L.). Environ. Exp. Bot. 139, 39-47. https://doi.org/10.1016/j.envexpbot.2017.04.002.

Bilger, W., Schreiber, U., 1986. Energy-dependent quenching of dark-level chlorophyll fluorescence in intact leaves. Photosyn. Res. 10, 303-308. https://doi.org/10.1007/ BF00118295.

Boari, F., Donadio, A., Schiattone, M.I., Cantore, V., 2015. Particle film technology: a supplemental tool to save water. Agric. Water Manag. 147, 154-162. https://doi. org/10.1016/j.agwat.2014.07.014.
Bradford, M.M., 1976. A rapid and sensitive method for the quantitation of microgram quantities of protein utilizing the principle of protein-dye binding. Anal. Biochem. 72, 248-254. https://doi.org/10.1006/abio.1976.9999.

Brito, C., Dinis, L.-T., Ferreira, H., Moutinho-Pereira, J., Correia, C., 2018a. The role of nighttime water balance on Olea europaea plants subjected to contrasting water regimes. J. Plant Physiol. 226, 56-63. https://doi.org/10.1016/j.jplph.2018.04.004.

Brito, C., Dinis, L.-T., Meijón, M., Ferreira, H., Pinto, G., Moutinho-Pereira, J., Correia, C., 2018b. Salicylic acid modulates olive tree physiological and growth responses to drought and rewatering events in a dose dependent manner. J. Plant Physiol. 230, 21-32. https://doi.org/10.1016/j.jplph.2018.08.004.

Brito, C., Dinis, L.-T., Ferreira, H., Rocha, L., Pavia, L., Moutinho-Pereira, J., Correia, C., 2018c. Kaolin particle film modulates morphological, physiological and biochemical olive tree responses to cyclic water deficit. Plant Physiol. Biochem. 133, 29-39. https://doi.org/10.1016/j.plaphy.2018.10.028.

Brito, C., Dinis, L.-T., Silva, E., Gonçalves, A., Matos, C., Rodrigues, M.A., MoutinhoPereira, J., Barros, A., Correia, C., 2018d. Kaolin and salicylic acid foliar application modulate yield, quality and phytochemical composition of olive pulp and oil from rainfed trees. Sci. Hortic. 237, 176-183. https://doi.org/10.1016/j. scienta.2018.04.019.

Brito, C., Dinis, L.-T., Moutinho-Pereira, J., Correia, C., 2019a. Drought stress effects and olive tree acclimation under a changing climate. Plants 8,232 . https://doi.org/ 10.3390/plants8070232.

Brito, C., Dinis, L.-T., Luzio, A., Silva, E., Gonçalves, A., Meijón, M., Escandón, M., Arrobas, M., Rodrigues, M.A., Moutinho-Pereira, J., Correia, C., 2019b. Kaolin and salicylic acid alleviate summer stress in rainfed olive orchards by modulation of distinct physiological and biochemical responses. Sci. Hortic. 246, 201-211. https:// doi.org/10.1016/j.scienta.2018.10.059.

Brito, C., Dinis, L.-T., Moutinho-Pereira, J., Correia, C., 2019c. Kaolin, an emerging tool to alleviate the effects of abiotic stresses on crop performance. Sci. Hortic. 250, 310-316. https://doi.org/10.1016/j.scienta.2019.02.070.

Brito, C., Dinis, L.-T., Ferreira, H., Coutinho, J., Moutinho-Pereira, J., Correia, C., 2019d. Salicylic acid increases drought adaptability of young olive trees by changes on redox status and ionome. Plant Physiol. Biochem. 141, 315-324. https://doi.org/ 10.1016/j.plaphy.2019.06.011.

Bryson, G., Mills, H.A., Sasseville, D.N., Jones, Jr J.B., Barker, A.V., 2014. Plant Analysis Handobook III. A Guide to Sampling, Preparation, Analysis and Interpretation for Agronomic and Horticultural Crops. Micro-Macro Publishing, Inc., Athens, GA.

Cansev, A., 2012. Physiological effects of high temperature treatments on leaves of olive cv. Gemlik. Plant Archives 12, 521-525. https://doi.org/10.1104/pp.32.1.61.

Cantore, V., Pace, B., Albrizio, R., 2009. Kaolin-based particle film technology affects tomato physiology, yield and quality. Environ. Exp. Bot. 66, 279-288. https://doi. org/10.1016/j. envexpbot.2009.03.008.

Ciríaco da Silva, E., Nogueira, R.J.M.C., Silva, M.A., Albuquerque, M.B., 2011. Drought stress and plant nutrition. J. Plant Stress. Physiol. 5, 32-41.

Cordeiro, A.M., Santos, L.C., Morais, N.C., 2013. As variedades da oliveira. In: Böhm, J. (Ed.), O grande Livro Da Oliveira E Do Azeite - Portugal Oleícola. Dinalivro Editora. Lisboa, Portugal, pp. 174-223.

Correia, C., Dinis, L.-T., Pinheiro, R., Fraga, H., Ferreira, H., Gonçalves, I., Costa, J., Oliveira, A., Malheiro, A., Moutinho-Pereira, J., 2014. Climate change and adaptation strategies for viticulture. J. Int. Sci. Publ.: Agric. Food 2, 424-429.

Denaxa, N.-K., Roussos, P.A., Damvakaris, T., Stournaras, V., 2012. Comparative effects of exogenous glycine betaine, kaolin clay particles and Ambiol on photosynthesis, leaf sclerophylly indexes and heat load of olive cv. Chondrolia Chalkidikis under drought. Sci. Hortic. 137, 87-94. https://doi.org/10.1016/j.scienta.2012.01.012.

Dinis, L.-T., Bernardo, S., Conde, A., Pimentel, D., Ferreira, H., Félix, L., Gerós, H., Correia, C.M., Moutinho-Pereira, J., 2016. Kaolin exogenous application boosts antioxidant capacity and phenolic content in berries and leaves of grapevine under summer stress. J. Plant Physiol. 191, 45-53. https://doi.org/10.1016/j. jplph.2015.12.005.

Dinis, L.-T., Bernardo, S., Luzio, A., Pinto, G., Meijón, M., Pintó-Marijuan, M., Cotado, A., Correia, C., Moutinho-Pereira, J., 2018. Kaolin modulates ABA and IAA dynamics and physiology of grapevine under Mediterranean summer stress. J. Plant Physiol. 220, 181-192. https://doi.org/10.1016/j.jplph.2017.11.007.

Downton, W.J.S., Loveys, B.R., Grant, W.J.R., 1988. Non-uniform stomatal closure induced by water stress causes putative non-stomatal inhibition of photosynthesis. New Phytol. 110, 503-509. https://doi.org/10.1111/j.1469-8137.1988.tb00289.x.

Ellman, G.L., 1959. Tissue sulfhydryl groups. Arch. Biochem. Biophys. 82, 70-77. https://doi.org/10.1016/0003-9861(59)90090-6.

Fernandes-Silva, A.A., Ferreira, T.C., Correia, C.M., Malheiro, A., Villalobos, F.J., 2010. Influence of different irrigation regimes on crop yield and water use efficiency of olive. Plant Soil 333, 35-47. https://doi.org/10.1007/s11104-010-0294-5.

Genty, B., Briantais, J.M., Baker, N.R., 1989. The relationship between the quantum yield of photosynthetic electron transport and quenching of chlorophyll fluorescence. Biochim. Biophys. Acta 990, 87-92. https://doi.org/10.1016/S0304-4165(89) 80016-9.

Gonçalves, A., Silva, E., Brito, C., Martins, S., Pinto, L., Dinis, L.-T., Luzio, A., MartinsGomes, C., Fernandes-Silva, A., Ribeiro, C., Rodrigues, M.Â., Moutinho-pereira, J., Nunes, F.M., Correia, C.M., 2020. Olive tree physiology and chemical composition of fruits are modulated by different deficit irrigation strategies. J. Sci. Food Agric. 100, 682-694. https://doi.org/10.1002/jsfa.10064.

Gregoriou, K., Pontikis, K., Vemmos, S., 2007. Effects of reduced irradiance on leaf morphology, photosynthetic capacity, and fruit yield in olive (Olea europaea L.). Photosynthetica 45, 172-181. https://doi.org/10.1007/s11099-007-0029-x.

Greven, M., Neal, S., Green, S., Dichio, B., Clothier, B., 2009. The effects of drought on the water use, fruit development and oil yield from young olive trees. Agric. Water Manag. 96, 1525-1531. https://doi.org/10.1016/j.agwat.2009.06.002. 
Heat, Packer, 1968. Peroxidation in isolated chloroplasts i. Kinetics and stoichiometry of fatty acid peroxidation. Arch. Biochem. Biophys. 125, 189-198. https://doi.org/ 10.1016/0003-9861(68)90654-1.

Hermoso, M., Uceda, M., Garcia, A., Morales, B., Frias, M.L., Férnandez, A., 1991. Elaboración De Aceite De Calidad. Junta De Andalucía. Consejería de Agricultura y Pesca, Sevilla, Spain.

Hodges, D.M., DeLong, J.M., Forney, C.F., Prange, R.K., 1999. Improving the thiobarbituric acid-reactive-substances assay for estimating lipid peroxidation in plant tissues containing anthocyanin and other interfering compounds. Planta 207, 604-611. https://doi.org/10.1007/s004250050524.

Hu, Y., Schmidhalter, U., 2005. Drought and salinity: a comparison of their effects on mineral nutrition of plants. J. Plant Nutr. Soil Sci. (1999) 168, 541-549. https://doi. org/10.1002/jpln.200420516.

IPCC, 2013. Climate change 2013: the physical science basis. In: Stocker, T.F., Qin, D., Plattner, G.-K., Tignor, M., Allen, S.K., Boschung, J., Nauels, A., Xia, Y., Bex, V., Midgley, P.M. (Eds.), Contribution of Working Group I to the Fifth Assessment Report of the Intergovernmental Panel on Climate Change, p. 1535. New York.

IPMA, 2019. Instituto Português Do Mar E Da Atmosfera (acessed 8 of August 2019). http ://www.ipma.pt/pt/oclima/normais.clima/.

Irigoyen, J.J., Einerich, D.W., Sánchez-Díaz, M., 1992. Water stress induced changes in concentrations of proline and total soluble sugars in nodulated alfalfa (Medicago sativd) plants. Physiol. Plant. 84, 55-60. https://doi.org/10.1111/j.1399-3054.1992. tb08764.x.

Jifon, J.L., Syvertsen, J.P., 2003. Kaolin particle film applications can increase photosynthesis and water use efficiency of `Ruby Red' grapefruit leaves. J. Am. Soc. Hortic. Sci. 128, 107-112. https://doi.org/10.21273/JASHS.128.1.0107.

Khaleghi, E., Arzani, K., Moallemi, N., Barzegar, M., 2015. The efficacy of kaolin particle film on oil quality indices of olive trees (Olea europaea L.) cv 'Zard' grown under warm and semi-arid region of Iran. Food Chem. 166, 35-41. https://doi.org/ 10.1016/j.foodchem.2014.06.006.

Koubouris, G.C., Kavroulakis, N., Metzidakis, I.T., Vasilakakis, M.D., Sofo, A., 2015. Ultraviolet-B radiation or heat cause changes in photosynthesis, antioxidant enzyme activities and pollen performance in olive tree. Photosynthetica 53, 279-287. https://doi.org/10.1007/s11099-015-0102-9.

Krause, G.H., Weis, E., 1991. Chlorophyll fluorescence and photosynthesis: the basics. Annu. Rev. Plant Physiol. Plant Mol. Biol. 42, 313-349.

Lichtenthaler, H.K., 1987. Chlorophylls and carotenoids: pigments of photosynthetic biomembranes. Methods Enzymol. 148, 350-382. https://doi.org/10.1016/00766879(87)48036-1.

Masmoudi, C.C., Ayachi, M.M., Gouia, M., Laabidi, F., Reguaya, S.B., Amor, A.O., Bousnina, M., 2010. Water relations of olive trees cultivated under deficit irrigation regimes. Sci. Hortic. 125, 573-578. https://doi.org/10.1016/j.scienta.2010.04.042.

Maxwell, K., Johnson, G.N., 2000. Chlorophyll fluorescence a practical guide. J. Exp. Bot. 51, 659-668. https://doi.org/10.1093/jxb/51.345.659.

McGrath, J.M., Lobell, D.B., 2013. Reduction of transpiration and altered nutrient allocation contribute to nutrient decline of crops grown in elevated $\mathrm{CO}_{2}$ concentrations. Plant Cell Environ. 36, 697-705. https://doi.org/10.1111/ pce. 12007.
Nanos, P.G., 2015. Leaf and fruit responses to kaolin particle film applied onto mature olive trees. J. Biol. Agric. Healthc. 5, 17-27.

Nogués, S., Baker, N.R., 2000. Effects of drought on photosynthesis in Mediterranean plants grown under enhanced UV-B radiation. J. Exp. Bot. 51, 1309-1317. https:// doi.org/10.1093/jxb/51.348.1309.

Prioul, J.L., Chartier, P., 1977. Partitioning of transfer and carboxylation components of intracellular resistance to photosynthetic $\mathrm{CO}_{2}$ fixation: a critical analysis of the methods used. Ann. Bot. 41, 789-800. https://doi.org/10.1093/oxfordjournals.aob. a085354.

Regulation, C., 1991. (EEC) No. 2568/91: On the characteristics of olive oil and olivepomace oil and on the relevant methods of analysis. Off. J. Eur. Union L248, 1-82.

Rodrigues, M.Â., Ferreira, I.Q., Claro, A.M., Arrobas, M., 2012. Fertilizer recommendations for olive based upon nutrients removed in crop and pruning. Sci. Hortic. 142, 205-211. https://doi.org/10.1016/j.scienta.2012.05.024.

Roussos, P.A., Denaxa, N.-K., Damvakaris, T., Stournaras, V., Argyrokastritis, I., 2010. Effect of alleviating products with different mode of action on physiology and yield of olive under drought. Sci. Hortic. 125, 700-711. https://doi.org/10.1016/j. scienta.2010.06.003.

Saour, G., Makee, H., 2003. Effects of kaolin particle film on olive fruit yield, oil content and quality. Adv. Hortic. Sci. 17, 204-206. https://www.jstor.org/stable/42883365.

Segura-Monroy, S., Uribe-Vallejo, A., Ramirez-Godoy, A., Restrepo-Diaz, H., 2015. Effect of kaolin application on growth, water use efficiency, and leaf epidermis characteristics of Physallis peruviana seedlings under two irrigation regimes. Agr. Sci. Tech. 17, 1585-1596.

Servili, M., Esposto, S., Fabiani, R., Urbani, S., Taticchi, A., Mariucci, F., Selvaggini, R., Montedoro, G.F., 2009. Phenolic compounds in olive oil: antioxidant, health and organoleptic activities according to their chemical structure. Inflammopharmacology 17, 76-84. https://doi.org/10.1007/s10787-008-8014-y. Sesták, Z., Castky, J., Jarvis, P.G., 1971. Plant Photosynthetic Production: Manual of Methods. Dr W. Junk Publishers, The Hague, Netherlands.

Shellie, K., Glenn, D.M., 2008. Wine Grape response to foliar particle film under differing levels of preveraison water Stress. HortScience 43, 1392-1397. https://doi.org/ 10.21273/HORTSCI.43.5.1392.

von Caemmerer, S., Farquhar, G.D., 1981. Some relationships between the biochemistry of photosynthesis and the gas exchange of leaves. Planta 153, 376-387. https://doi. org/10.1007/BF00384257.

Walinga, I., van Vark, W., Houba, V., van der Lee, J., 1989. Soil and Plant Analysis: Part 7- Plant Analysis Procedures. Wageningen Agricultural University, The Netherlands.

WRB, 2014. World Reference Base for Soil Resources. International Soil Classification System for Naming Soils and Creating Legends for Soil Maps. World Soil Resources Reports No. 106. FAO, Rome.

Ye, Z.-P., 2007. A new model for relationship between irradiance and the rate of photosynthesis in Oryza sativa. Photosynthetica 45, 637-640. https://doi.org/ 10.1007/s11099-007-0110-5.

Zhang, D., Du, Q., Zhang, Z., Jiao, X., Song, X., Li, J., 2017. Vapour pressure deficit control in relation to water transport and water productivity in greenhouse tomato production during summer. Sci. Rep. 7, 43461. https://doi.org/10.1038/srep43461. 